九州大学学術情報リポジトリ

Kyushu University Institutional Repository

\title{
Recycling Wastewater in Intensive Swine Farms: Selected Case Studies in Vietnam
}

\section{GIANG, Nguyen Thi Huong}

Faculty of Environmental Sciences, Vietnam National University of Agriculture

AN, Ngo The

Department of Environment and Forest Resources, College of Agriculture \& Life Sciences, Chungnam National University

HUONG, Le Thi Thu

Faculty of Accounting and Business Management, Vietnam National University of Agriculture

YABE, Mitsuyasu

Department of Agricultural and Resource Economics, Faculty of Agriculture, Kyushu University

他

https://doi.org/10.5109/4363559

出版情報: 九州大学大学院農学研究院紀要. 66 (1)，pp.115-121，2021-03-01. Faculty of Agriculture, Kyushu University

バージョン :

権利関係 : 


\title{
Recycling Wastewater in Intensive Swine Farms: Selected Case Studies in Vietnam
}

\author{
Nguyen Thị Huong GIANG ${ }^{1,2}$, Ngo The AN ${ }^{1}$, Le Thi Thu HUONG ${ }^{3}$, Mitsuyasu YABE, \\ Nguyen Tat THANG ${ }^{4}$, Vu Ngoc HIEU ${ }^{5}$ and Cao Truong $\mathrm{SON}^{1 *}$
}

\author{
Laboratory of Environmental Economics, Department of Agricultural and Resource Economics, \\ Faculty of Agriculture, Kyushu University, 819-0395, Fukuoka, Japan \\ (Received October 28, 2020 and accepted November 4, 2020)
}

\begin{abstract}
Recycling livestock wastewater has been promoted as an appropriate pathway to attain animal waste mitigation and contribute to circular economy. In comparison to other livestock, swine production is considered as a potential sector for wastewater reuse because of its' rich nutrient. However, in developing countries, livestock wastewater was claimed to be one of the main sources of water pollution due to the poor treatment and inefficient usage. In order to provide information for further policies aiming at recycling this type of resources, this study investigate how swine farms currently manage their wastewater and identify some major challenges. Questionnaire interviews were conducted in 123 intensive swine farms located in four provinces: Ha Noi, Thai Binh, Ha Tinh and Dong Nai. The results showed that, recycling wastewater has been accepted by a haft of intensive swine farms, although the national technical standard on reuse of livestock wastewater has not been legally promulgated. The farms use wastewater to irrigate different types of plants such as fruit trees, vegetable and cash trees. While $37.4 \%$ of swine farms applying wastewater to fruit trees, only $15.4 \%$ and $8.9 \%$ of the farms used it to irrigate vegetable and cash trees, respectively. However, the wastewater samples analysis of nine farms pointed out that, many other components of swine wastewater might be harmful for environment and other living organism, especially coliform contamination. The study proposes that, reusing wastewater is an appropriate solution to increase the efficient use of water in swine production, provided that specific technical standards are required to minimize risks to the environment and other production activities.
\end{abstract}

Key words: swine production, wastewater reuse, circular economy, water pollution

\section{INTRODUCTION}

Reusing wastewater of livestock farming has been widely recommended by scientists and international organizations. It is scientifically confirmed that the effluents from livestock farms contain rich nutrients, becoming a valuable resource for farming activities. However, WHO, UNEP and FAO and many other researchers all had the similar concerns about the health risks when wastewater being reused (Blumenthal et al., 2000; Mara et al., 1989; WHO, 2006, 1989).

According to the report of Ministry of Natural Resource and Environment (MONRE, 2018), water quality in Vietnam has been declining significantly due to the massive pressures produced from domestic, industrial, and agricultural activities. In agricultural sector, the wastewater released into the river basins per day from livestock farming accounted for approximately 6.6 million $\mathrm{m}^{3}$, one of the greatest pollution sources. Of which, the amount of wastewater from piggery was estimated around 5.6 million $\mathrm{m}^{3}$ per day, much higher than that of

\footnotetext{
${ }^{1}$ Faculty of Environmental Sciences, Vietnam National University of Agriculture

${ }^{2} \mathrm{PhD}$ student, Vietnam National University of Agriculture (nthgiang.qlmt@vnua.edu.vn)

Faculty of Accounting and Business Management, Vietnam National University of Agriculture

${ }^{4}$ Faculty of Education and Foreign Languages, Vietnam National University of Agriculture

${ }^{5}$ Department of Science Technology and Environment, Vietnam Ministry of Agriculture and Rural Development

* Corresponding author (Email: caotruongson.hua@gmail.com)
}

the cow and buffalo farming with about 1 million $\mathrm{m}^{3}$ per day (MONRE, 2018). The situation even becomes more seriously because farmers in Vietnam have been shifting from household to industrial production scale. Both farmers and environmental institutions have been challenged with the wastewater management, which was claimed to be the causes of many environmental problems surround farming areas (An et al., 2020; Ho et al., 2013, 2010; Huong et al., 2020). Hitherto, the government has been on the process of authorizing specific national technical standards to promote the reuse of livestock wastewater. This act performs an attempt to achieve a win-win solution to control the water pollution and water scarcity situation in agriculture sector.

In order to promoting livestock wastewater recycling in Vietnam, we firstly analyze the methods of water use and wastewater recycling of intensive pig farms. In addition, the end-use wastewater samples were collected and analyzed to find out the technical problems which might trigger if it becomes irrigation water. The results of this study provide supplement information which assist policy makers in making decisions with efforts to recycle wastewater.

\section{STUDY AREAS AND RESEARCH METHODS}

\section{Study areas}

The study was conducted in four provinces: Ha Noi, Thai Binh, Ha Tinh and Dong Nai. In 2019, these provinces took nearly $20 \%$ of total swine production of Vietnam. Dong Nai had the largest number of swine head with over 2.4 billion heads in 2019. Ha Noi took the 
second place with over 1.7 billion swine head in 2019 . However, in term of swine population density, Thai Binh was the highest swine density with 634 head per square kilometer, according to the statistics in 2020. The swine density of Ha Noi and Dong Nai was 512 and 415 head per square kilometer respectively. Compare to other three provinces, Ha Tinh had the smallest production with only 391 thousand swine heads in 2019, lightly increased comparing to 2010 (Figure 2). The swine population density of this area was only 65 head per square kilometer, much lower than the density of three other provinces.

Despite the differences, all provinces have been experiencing the transition of farming scale as well as the increase of pressure from swine waste. The increase

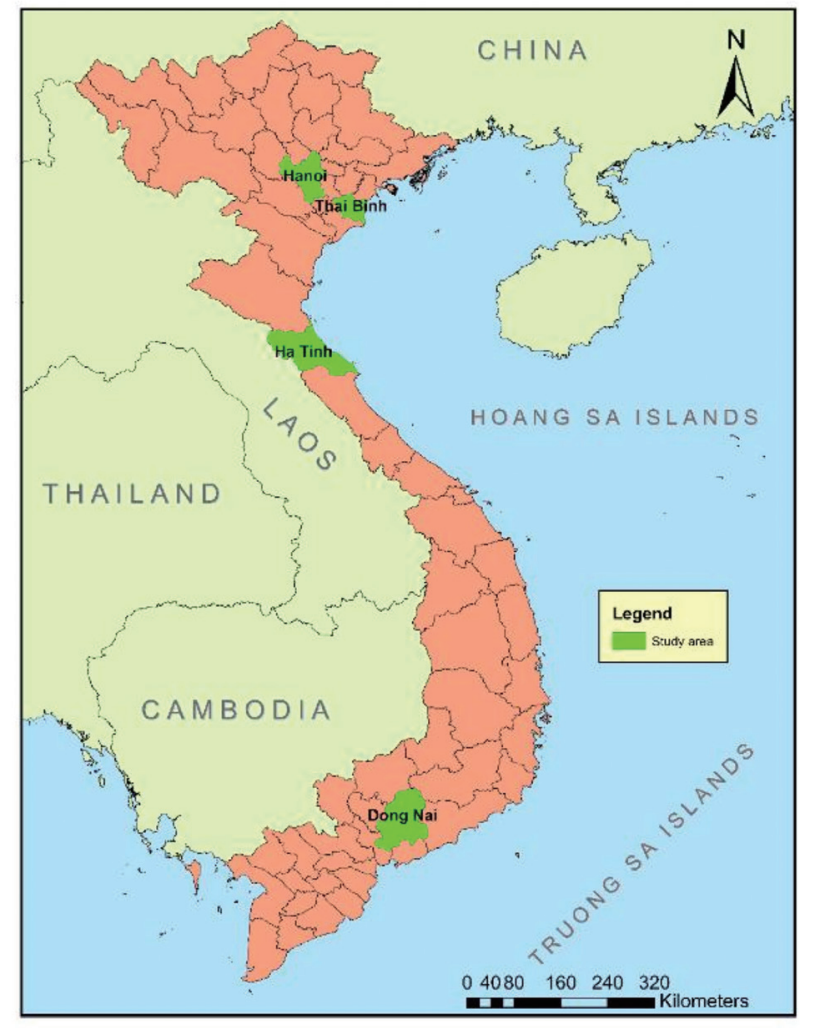

Fig. 1. Locations of Ha Noi, Thai Binh, Ha Tinh and Dong Nai

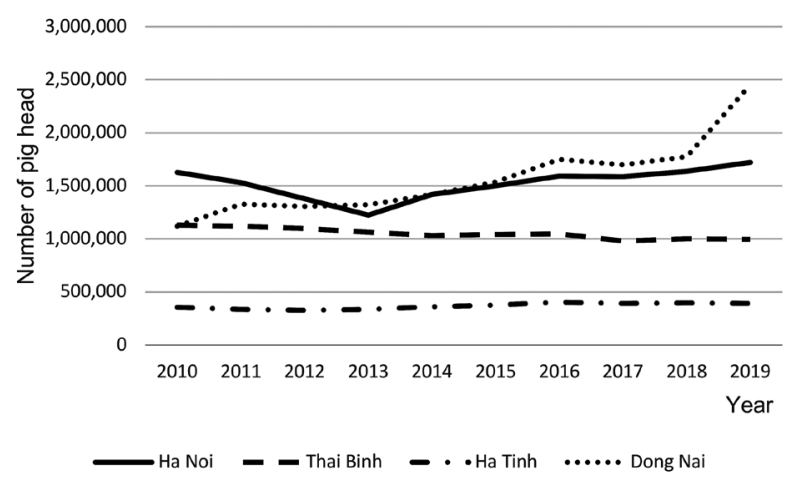

Fig. 2. Swine production in Ha Noi, Thai Binh, Ha Tinh anh Dong Nai

Source: Summary from annual statistics of the Department of Livestock Production from 2011 to 2020 of intensive farming systems and the expansion of farm scale happened coincide with the growth of waste concentration. The swine waste could be source of pollution however, it could be valuable if farmers in these areas apply appropriate solution.

\section{Farm Survey}

The interviews were conducted in 123 swine farms of the four provinces. We randomly selected 33 farms in Hanoi and 30 farms in each of remaining provinces. The questionnaire presents the situation of managing and reusing wastewater in intensive swine farms in different areas of Vietnam.

\section{Water sampling and analysis}

Among 123 swine farms, wastewater samples of 9 farms were analyzed to identify the quality of wastewater before being discharged into the environment. The characteristics of farms and samples location are described in Table 1. Each sample was analyzed to find out the concentration of Biological Oxygen Demand (BOD), Chemical Oxygen Demand (COD), Total Solid Suspended (TSS), Coliform, Total Nitrogen (TN) and Total Phosphorus (TP) and some heavy metals which are Arsenic (As), Copper (Cu), Lead (Pb) and Zinc (Zn).

Each farm, we took one wastewater sample at the reservoir point (before discharging into the environment or irrigating). Each sample was analyzed to find out the concentration of BOD, COD, TSS, TN, TP, Cu, Pb, Zn, Cd and As. The analysis method to each parameter was summarized in Table 2.

\section{Data analysis}

The study applied the SPSS 22 to process the data. We used crosstab computation and other descriptive methods to provide the general descriptions of swine farms, water use and wastewater reuse situation. The wastewater quality was assessed by the QCVN62: 2016/ BTNMT- Vietnam National technical regulation on the effluent of livestock, and the Draft of Vietnam National technical regulation on livestock wastewater for irrigation.

\section{RESULTS AND DISCUSSIONS}

\section{Farm characteristics}

Table 3 shows that, characteristics of farms in four provinces differ significantly each other. The swine farms of Dong Nai province had the largest production scale with average 4,922 swine head per farm. The average area of swine barns in this province also ranked at the first position, with $5,524 \mathrm{~m}^{2}$ per barn averagely. The province which had the largest average area of farmland was Ha Tinh, over $42,446 \mathrm{~m}^{2}$ per farm, nearly double higher than Dong Nai, seven times higher than Ha Noi and nearly 9 times higher than the farms of Thai Binh. However, Ha Tinh was only 1,500 swine head per farm, equal to Thai Binh province and much lower than Ha Noi and Dong Nai. Ha Noi was the second largest production scale with the average number of swine per farm was 
Table 1. Characteristics of the farms taken water samples

\begin{tabular}{llllcc}
\hline No. & Location & Longitudes & Latitudes & Pig (quantity/year) & Farm area $\left(\mathrm{m}^{2}\right)$ \\
\hline Farm 1 & Thai Binh & $106^{\circ} 29^{\prime} 85^{\prime \prime}$ & $20^{\circ} 53^{\prime} 81^{\prime \prime}$ & 500 & 3,000 \\
Farm 2 & Thai Binh & $106^{\circ} 34^{\prime} 59^{\prime \prime}$ & $20^{\circ} 54^{\prime} 4^{\prime \prime}$ & 250 & 7,200 \\
Farm 3 & Thai Binh & $1^{\prime} 6^{\circ} 33^{\prime} 20^{\prime \prime}$ & $20^{\circ} 48^{\prime} 08^{\prime \prime}$ & 3,000 & 51,400 \\
Farm 4 & Ha Tinh & $105^{\circ} 65^{\prime} 06^{\prime \prime}$ & $18^{\circ} 42^{\prime} 8^{\prime \prime}$ & 500 & 50,000 \\
Farm 5 & Ha Tinh & $105^{\circ} 52^{\prime} 3^{\prime \prime}$ & $18^{\circ} 16^{\prime} 48^{\prime \prime}$ & 1,250 & 23,118 \\
Farm 6 & Ha Tinh & $105^{\circ} 55^{\prime} 44^{\prime \prime}$ & $18^{\circ} 23^{\prime} 1^{\prime \prime}$ & 2,000 & 30,000 \\
Farm 7 & Dong Nai & $107^{\circ} 12^{\prime} 44^{\prime \prime}$ & $10^{\circ} 34^{\prime} 10^{\prime \prime}$ & 1,400 & 50,000 \\
Farm 8 & Dong Nai & $107^{\circ} 12^{\prime} 04^{\prime \prime}$ & $10^{\circ} 51^{\prime} 26^{\prime \prime}$ & 900 & 10,147 \\
Farm 9 & Dong Nai & $107^{\circ} 21^{\prime} 46^{\prime \prime}$ & $10^{\circ} 57^{\prime} 11^{\prime \prime}$ & 900 & 30,000 \\
\hline
\end{tabular}

Table 2. Water samples analysis methods

\begin{tabular}{cll}
\hline No. & Parameters & \\
\hline 1 & DO & Measured on site by a portable DO meter (D-50 Series, Horiba, Co. Ltd). \\
2 & COD & Analyzed by dichromate method (Cr ${ }^{6+}$ ) (SMEWW 5220C: 2012). \\
3 & BOD & Analyzed by dilution method and cultured at 20 ${ }^{\circ}$ C (SMEWW 5210B: 2012) \\
4 & TN & Analyzed by Kjeldahl method (SMEWW4500. Norg. A. B. C) \\
5 & TP & Analyzed by Ammonium molybdate spectrometric method (ISO 6878: 2004) \\
6 & TSS, & Analyzed by filtration through glass filters (SMEWW 2540B : 2012) \\
7 & Coliform & Analyzed by colony counting methods (ISO 10304-1: 2007) \\
8 & As, Cu, Pb and & Analyzed by atomic absorption spectrometry (ASS), respectively, at 350 nm \\
& Zn & wavelengths for As; 324.8 nm for Cu; 217 nm for Pb; and 213.9 for Zn (EPA Method \\
& &
\end{tabular}

Table 3. Characteristics of pig farms in study areas

\begin{tabular}{lccccc}
\hline \multirow{2}{*}{$\begin{array}{l}\text { Characteristics } \\
\text { Unit }\end{array}$} & $\begin{array}{c}\text { Hanoi } \\
\mathrm{N}=33\end{array}$ & $\begin{array}{c}\text { Thai Binh } \\
\mathrm{N}=30\end{array}$ & $\begin{array}{c}\text { Ha Tinh } \\
\mathrm{N}=30\end{array}$ & $\begin{array}{c}\text { Dong Nai } \\
\mathrm{N}=30\end{array}$ \\
\cline { 3 - 5 } & & Mean (SD) & Mean (SD) & Mean (SD) & Mean (SD) \\
\hline \multirow{2}{*}{ Average pig head per year } & \multirow{2}{*}{ Head } & $2,354.36$ & $1,542.00$ & $1,504.30$ & $4,922.66$ \\
& & $(7,893.12)$ & $(2,223.16)$ & $(1,042.37)$ & $(7,410.88)$ \\
Average farm area & $5,796.63^{* * *}$ & $4,723.26^{* * *}$ & $42,446.40^{* * *}$ & $27,955.10^{* * *}$ \\
& \multirow{2}{*}{$\mathrm{m}^{2}$} & $(10,098.45)$ & $(9,898.85)$ & $(45,377.04)$ & $(31,106.46)$ \\
Average barn area & & $1,428.78^{* *}$ & $681.66^{* *}$ & $2,117.63^{* *}$ & $5,524.86^{* *}$ \\
& \multirow{2}{*}{$\mathrm{m}^{2}$} & $(3,396.36)$ & $(1,124.32)$ & $(2,133.41)$ & $(11,109.89)$ \\
\hline
\end{tabular}

Standard deviations are given in parentheses; $n=$ number of pig-farming

***P-value $\leq 0.001 ; * * P$-value $\leq 0.05$

2,354. However, it had much lower average farm area and barn area in comparison to the first place, Dong Nai province. We used ANOVA analysis to test the significant differences of farm characteristics of four provinces. The results showed that the differences of farming scale are nearly significant with $\mathrm{P}$-value slightly greater than $0.05(\mathrm{P}=0.066)$ and the mean values of farm area and barn area are all significant with $\mathrm{P}<0.01$. We could conclude the differences of farms' characteristics among four provinces. These differences potentially related to the waste treatment situation in each area. This claim has been proved by many studies in practice (Basset-Mens \& Werf, 2005; Williams et al., 2006).

Table 4 provides information about waste treatment methods of the surveyed farms. Generally, the intensive swine farm deployed well in implementing waste treatment measures. There was over 98\% of farms applying biogas systems, 59\% of farms separating or partly separating solid and liquid waste before treatment (Table 4). In addition, around one-third of interviewed farms have bio-ponds for further treatment after biogas tanks, 28\% of farms have fishponds as a measure for wastewater treatments.

Among four provinces, swine farms in Ha Tinh preferred treating the wastewater by bio-ponds and fishponds with $90 \%$ and $46 \%$, respectively, because they have larger land area. Otherwise, only about $15 \%$ of surveyed farm in Ha Noi had bio-ponds. The application rate of bio-pond in Dong Nai was slightly higher at 35\% but still lower than Ha Tinh Province. The bio-ponds is 
Table 4. Waste treatment methods of surveyed farms

\begin{tabular}{lccccc}
\hline & $\begin{array}{c}\text { Hanoi } \\
(\mathrm{n}=33)\end{array}$ & $\begin{array}{c}\text { Thai Binh } \\
(\mathrm{n}=30)\end{array}$ & $\begin{array}{c}\text { Ha Tinh } \\
(\mathrm{n}=30)\end{array}$ & $\begin{array}{c}\text { Dong Nai } \\
(\mathrm{n}=30)\end{array}$ & $\begin{array}{c}\text { Whole study area } \\
(\mathrm{n}=123)\end{array}$ \\
\hline Freq.(\%) & Freq.(\%) & Freq.( \%) & Freq.(\%) & Freq.(\%) \\
\hline $\begin{array}{l}\text { Partly separate solid and } \\
\text { liquid waste }\end{array}$ & $12(36.4)$ & $30(100.0)$ & $18(60.0)$ & $13(43.3)$ & $73(59.3)$ \\
Compost & $7(21.2)$ & $12(40.0)$ & $13(43.3)$ & $8(26.7)$ & $40(32.5)$ \\
Biogas & $32(97.0)$ & $29(96.7)$ & $30(100.0)$ & $30(100.0)$ & $121(98.4)$ \\
Bio-pond & $5(15.2)$ & $4(13.3)$ & $27(90.0)$ & $10(34.5)$ & $46(37.7)$ \\
Fishpond & $8(24.2)$ & $9(30.0)$ & $14(46.7)$ & $4(13.3)$ & $35(28.5)$ \\
\hline
\end{tabular}

$N=$ Number of pig-farming

Table 5. Water sources for production and water reuse status of surveyed swine farms

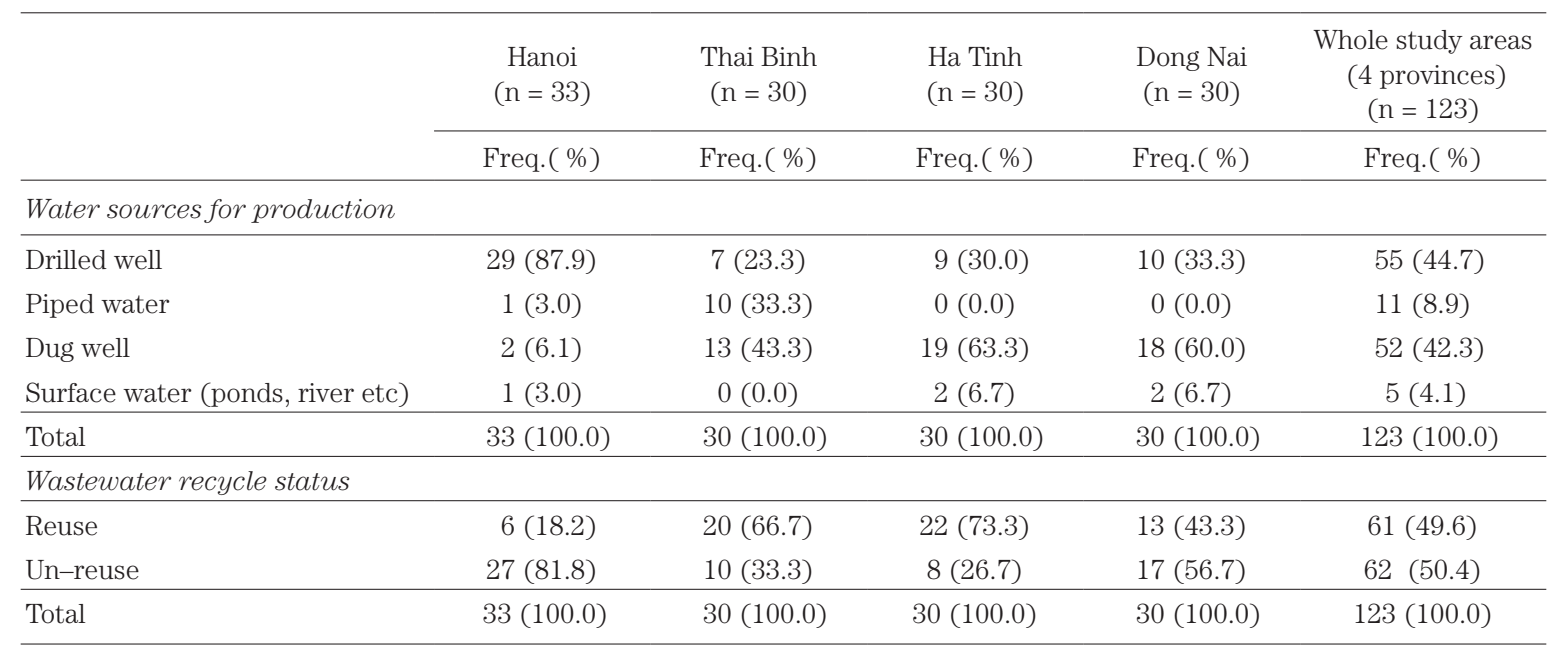

generally believed to be effective measures for organic matters and micro-biological contamination removals from the effluents (Etnier and Guterstam, 2013). With the high concentration of waste in intensive swine farm, bio-ponds is an appropriate secondary solution for wastewater treatment after biogas.

\section{Water use and wastewater recycling in swine farms}

Swine farming is claimed to be the most water wasteful consumption farming system comparing to other animals. Wastewater from swine farms is a combination of drinking water, cleaning water, cooling water, and swine urine. According to $\mathrm{Vu}$ et al. (2007) the volume of washing water was about 40 litters per swine per day. Drinking water measured could achieved 6.9 litter per swine (Van et al., 2017). In 2018, the MONRE cited a much lower wastewater coefficient released from piggery with only 20 litters per swine per day (MONRE, 2018). However, all researchers asserted that, swine production is the most consumed water in comparison to other livestock. Thus, water consumption and water use sources directly connect to other water problems (water pollution and water shortage) around swine farms.

Table 5 summarizes the use of water sources in the farms of four provinces. Drilled and dug wells were the main sources of water-use in intensive farms. The swine farms in Ha Noi mostly used drilled wells (88\%).
Otherwise, over $60 \%$ of farms in Ha Tinh and Dong Nai using the water from dug wells. The study also found out that, there was a significant number of farms applying piped water for feeding swine. In Thai Binh, there were $30 \%$ of surveyed farms applied piped water in production process. The farms which used surface water took a small proportion in total, only $4 \%$ of the surveyed farms.

Water consumption of swine farms highly impact on the ground water reserves. Nearly one hundred percentage of surveyed farms used ground water from dug wells or drilled wells for farming. Each day, an intensive swine farm would consume large amount of water and discharged it into the environment in the form of wastewater. According to the coefficient of wastewater generated from pig farming of MONRE, the largest farm in the survey with 44,800 head might produce 896,000 litters of wastewater per day. The smallest farm also might generate 3,000 litters of wastewater per day. Effluent from swine farms was not only increase the pressure on the environment but also threaten the local water reserves. Saving water and converting wastewater into resources are the expectation of both farmers and policy makers (Nguyen, 2018; Thanh Son \& Nguyen Thuy, 2019; Vinh, 2013). Some managers of livestock enterprises even claimed that, it was not necessary to have regulations for livestock wastewater if it is used for irrigation purpose (Thanh Son \& Nguyen Thuy, 2019). 
In the study, we found that, half of the farms had been started using swine wastewater for irrigation (Table 6). Around two-third of surveyed farms in Thai Binh and Ha Tinh has reused wastewater. The rate of water reuse was around $43 \%$ and $18 \%$ of surveyed farms in Dong Nai and Hanoi. The swine farm owners use the wastewater mostly in their farm's land, indicating the connection between farms' size, farms' crops and water reuse situation. In Thai Binh and Ha Tinh, most of the farms is large-scale. In addition, the farm owners still maintain others farming activities, especially crop cultivation inside farm's land. In Dong Nai province, the swine farms with garden systems are still observed, while the systems are rare in Ha Noi. In Vietnam, the farm, which had livestock production, garden and fishponds, was named Vuon - Ao - Chuong (VAC system). The VAC was claimed to have fewer negative impacts on the environment, especially surface water (Ho et al., 2013). For reusing swine wastewater, the farms with gardens also have better advantages.

The swine farms utilize the wastewater for variety of purposes, which are presented in Table 6. There were $37 \%$ of total surveyed farms irrigating their fruits, $15 \%$ of farms used wastewater for cash crops or wooden trees, $9 \%$ using wastewater to irrigate vegetable and only $4 \%$ irrigated paddy rice by swine wastewater. Ha Tinh and Thai had over a haft of the surveyed farms which reused wastewater for their fruit garden. In Dong Nai, there was $30 \%$ and $26 \%$ of the farms irrigating fruits trees and cash crops, respectively. Ha Noi was the province using swine wastewater at the lowest rate and there were 5 out of 33 farms in this province used it to water the vegetable.

The wastewater reuse situation of intensive swine farms in the study areas provides a reality that although the government have not promulgated legal regulations on livestock wastewater used in irrigation, farmers had already perceived it likes a waste treatment application in their farms. The nutrient contained in the wastewater could provide good inputs for crop growth and additional incomes for farmers. However, the purposes of wastewater reflect another risk of wastewater recycling when many farms applied it for food crops, especially vegetable and fruit trees (Delli et al., 2020; Helmecke et al., 2020; Jaramillo \& Tarquino, 2017). The following section we going to discuss the wastewater quality of some typical intensive farms located in studies area.

\section{Wastewater characteristics of swine farms}

In order to access the wastewater quality of swine farm after treatment, 9 water samples 9 farms were taken and analyzed. Of which, six out of nine farms reused wastewater (Table 7). The wastewater quality was assessed by two national technical standards on livestock wastewater of Vietnamese government. Firstly, the wastewater quality was compared to the current national regulations on the effluent of livestock to access the compliance of wastewater quality from swine if it is discharged to environment. Secondly, we used the Draft of National technical regulation on the effluent of livestock used in crop production to access the suitability of swine wastewater for agriculture purposes.

The farms' wastewater system of 9 sampling farms performed significant effort in processing wastewater. All farms had biogas plant and most of farms designed the bio-pond system for further treatment of effluent after biogas. However, the results pointed that, despite the significant investment in wastewater treatment system, many parameters of swine wastewater were not satisfied the requirement of formal regulations, especially, the coliforms parameter (Table 7). A haft of farms also has the TSS, the COD, BOD and the TN exceeded the standard of regulations. According to the national law, if the water is discharged into environment, these farms will be given an administrative monetary penalty.

The wastewater quality of nine farms in the survey showed that, there was a big gap between wastewater quality and the threshold values of the national technical standards, though the farms installed storage tank, biogas and bio-ponds. Furthermore, the results of the survey on 123 farms found out, only one-third of intensive swine farms had the better system with further treatment system after biogas. Most of farm only have biogas plant and without additional treatment methods (Ho et al., 2013). Under the low enforcement of local institutions, the wastewater was discharged into environment and caused water pollution. This problem had been claimed in many papers which identified the impacts of swine farming on environment (An et al., 2020; Cao et al., 2011; Cassou et al., 2017). Therefore, the larger scale of swine farming without effective wastewater treatment could become serious sources of water quality degradation.

The second circumstance, we assumed that the draft of National technical regulation on the effluent of live-

Table 6. Irrigation purposes of swine wastewater in surveyed farms

\begin{tabular}{|c|c|c|c|c|c|}
\hline & $\begin{array}{c}\text { Hanoi } \\
(\mathrm{n}=33)\end{array}$ & $\begin{array}{l}\text { Thai Binh } \\
(n=30)\end{array}$ & $\begin{array}{l}\text { Ha Tinh } \\
(n=30)\end{array}$ & $\begin{array}{l}\text { Dong Nai } \\
(\mathrm{n}=30)\end{array}$ & $\begin{array}{c}\text { Whole study areas } \\
\text { (4 provinces) } \\
(\mathrm{n}=123)\end{array}$ \\
\hline & Freq. (\%) & Freq. (\%) & Freq. (\%) & Freq. (\%) & Freq. (\%) \\
\hline Vegetable & $5(15.2)$ & $5(16.7)$ & $0(0.0)$ & $1(3.3)$ & $11(8.9)$ \\
\hline Fruit Trees & $4(12.1)$ & $17(56.7)$ & $15(50.0)$ & $10(33.3)$ & $46(37.4)$ \\
\hline Wooden and Cash tree & $0(0.0)$ & $1(3.3)$ & $10(33.3)$ & $8(26.7)$ & $19(15.4)$ \\
\hline Paddy Rice & $1(3.0)$ & $0(0.0)$ & $3(10.0)$ & $1(3.3)$ & $5(4.1)$ \\
\hline Total & $10(30.3)$ & $23(76.7)$ & $28(93.3)$ & $20(66.7)$ & $81(65.9)$ \\
\hline
\end{tabular}


Table 7. Wastewater characteristic of randomly selected farms

\begin{tabular}{|c|c|c|c|c|c|c|}
\hline \multirow[b]{2}{*}{ Parameter } & \multirow[b]{2}{*}{ Unit } & \multirow{2}{*}{$\begin{array}{c}\text { Average } \\
\pm \mathrm{SD}\end{array}$} & \multicolumn{2}{|c|}{ QCVN62/BTNMT } & \multicolumn{2}{|c|}{ Draft QCVN* } \\
\hline & & & Threshold & $\begin{array}{c}\text { Rate of exceed } \\
\text { the standard }\end{array}$ & Threshold & $\begin{array}{c}\text { Rate of exceed } \\
\text { the standard }\end{array}$ \\
\hline $\mathrm{pH}$ & - & $\begin{array}{l}7.86 \\
\pm 0.44\end{array}$ & $5.5-9.0$ & 0 & $5.5-9.0$ & 0 \\
\hline TSS & $\mathrm{mg} / \mathrm{L}$ & $\begin{array}{c}162.7 \\
\pm 133.3\end{array}$ & 150 & 33.3 & - & - \\
\hline COD & $\mathrm{mg} / \mathrm{L}$ & $\begin{array}{c}505.3 \\
\pm 706.9\end{array}$ & 300 & 44.4 & - & - \\
\hline BOD & $\mathrm{mg} / \mathrm{L}$ & $\begin{array}{c}240.9 \\
\pm 313.7\end{array}$ & 100 & 55.6 & - & - \\
\hline $\mathrm{TN}$ & $\mathrm{mg} / \mathrm{L}$ & $\begin{array}{c}126.7 \\
\pm 259.7\end{array}$ & 150 & 11.1 & - & - \\
\hline $\mathrm{TP}$ & $\mathrm{mg} / \mathrm{L}$ & $\begin{array}{l}28.9 \\
\pm 24\end{array}$ & - & - & - & - \\
\hline Coliform & MPN/100 mL & $\begin{array}{c}49.1 \times 10^{3} \\
\pm 87.9 \times 10^{3}\end{array}$ & $5 \times 10^{3}$ & 66.7 & $7.5 \times 10^{3}$ & 55.6 \\
\hline $\mathrm{Cu}$ & $\mu \mathrm{g} / \mathrm{L}$ & $\begin{array}{c}21.6 \\
\pm 19.4\end{array}$ & - & - & 500 & 0 \\
\hline $\mathrm{Pb}$ & $\mu \mathrm{g} / \mathrm{L}$ & $\begin{array}{c}5.8 \\
\pm 2.9\end{array}$ & - & - & 50 & 0 \\
\hline $\mathrm{Zn}$ & $\mu \mathrm{g} / \mathrm{L}$ & $\begin{array}{c}1,218.3 \\
\pm 2,037.8\end{array}$ & - & - & 2.000 & 11.1 \\
\hline $\mathrm{Cd}$ & $\mu \mathrm{g} / \mathrm{L}$ & $\begin{array}{c}0.7 \\
\pm 1.3\end{array}$ & - & - & 10 & 0 \\
\hline As & $\mu \mathrm{g} / \mathrm{L}$ & $\begin{array}{c}2.3 \\
\pm 1.0\end{array}$ & - & - & 50 & 0 \\
\hline
\end{tabular}

Note: *Draft of National technical regulation on the effluent of livestock used in crop production

stock used in crop production being promulgated, the wastewater quality was compared to some threshold values of this document. The proposed national technical standard mostly concerns about the heavy metal contaminations and the microbial contaminations. The comparison results are showed in Table 7 .

The results show better circumstance in the case of wastewater being used as irrigation water. All the wastewater samples were met the threshold values of heavy metals. However, only under 50\% farms' wastewater satisfied the coliform contamination requirement.

The nutrient contained in the wastewater could provide good inputs for crop growth, but the purposes of wastewater draw out another risk. Nearly 10\% of farms used this type of water to irrigate their vegetable and above $90 \%$ of farms used it to water their fruit trees which fruits might be consumed freshly, for examples rambutan, Kumquat, oranges, etc. The data in Table 7 showed that, the quality of wastewater still contains significant coliform contaminants. Thus, if it is used for fresh food crops, it might cause waterborne diseases and other health impacts on consumers. The problems of micro-biological contamination on fresh food had been found in many studies (Chau et al., 2014; MachadoMoreira et al., 2019). Nevertheless, the use of wastewater for cash crops and wooden trees is potentially efficient if it is managed properly. According to the farms' characteristics, Dong Nai, especially Ha Tinh province has appropriate conditions to reuse swine wastewater for these types of trees, compare to two other provinces.

\section{CONCLUSIONS}

Recycling wastewater could become an appropriate pathway to attain waste mitigation and sustainable use of natural resources. In comparison to other types of wastewater, swine wastewater is considered as a potential sector for wastewater reuse, because it might contain low heavy metals and more nutrient than other wastewater sources.

The study provides useful information of water reused in intensive farming system in some areas of Vietnam. The results showed that, there were a haft of farms which have been reusing swine wastewater, however, it is not equally for all areas. Some provinces we observed significant proportion of wastewater reuse, but some others were less. The province which have the large average farmland and maintain garden activities, wastewater reuse become more popular. The wastewater was reused in multiple purposes of crop irrigations. However, it promises the most safety impacts when being used to irrigate wooden trees, cash crops and other none-fresh consumption products. However, the use of wastewater for vegetable irrigation and other fresh consumption crops might produce potential risks because of the high concentration of coliforms, even after secondary treatments systems.

With the findings, study concludes that, recycling 
swine wastewater could bring potential positive impacts to environment as well as farms' owners. However, the treatment measure before recycling is necessary to reduce harmful contaminants. Especially, the specific usages of wastewater should be clearly regulated to avoid unexpected consequence in the environment and human health. Moreover, to promote the wastewater reuse, the policies should focus on farm's land expansion and develop VAC systems.

\section{AUTHOR CONTRIBUTIONS}

Nguyen Thi Huong GIANG: Idea development, Study design, Data collection and analysis, Wrote original manuscript, Editing; Ngo The AN: Idea development, Suppervision - Review and editing; Le Thi Thu HUONG: Writing - Review and editing; Mitsuyasu YABE: Conceptualization, Review and Editing, Supervision; Nguyen Tat THANG: Data collection and Data analysis, Review; Vu Ngoc HIEU: Review and Editing; Cao Truong SON: Conceptualization, Methodology, Visualization, Editing and Supervision.

\section{ACKNOWLEDGEMENTS}

The research is funded by of Vietnam Ministry of Agriculture and Rural Development (Vietnam MARD) in Project "Applying waste audit and proposing solutions for environmental protection in pig production". Project Code: B3-2.

\section{REFERENCES}

An, N. T., Lan, N. P., Cong, V. H., Duong, N. H., \& Giang, N. T. H. 2020. Environmental Pressure from Pig Farming to Surface Water Quality Management in Yen Dung District Bac Giang Province. VNU Journal of Science: Earth and Environmental Sciences, 36(1), 45-52

Basset-Mens, C., \& Werf, H. van der. 2005. Scenario-based environmental assessment of farming systems: The case of pig production in France. Agriculture, Ecosystems \& Environment, $\mathbf{1 0 5}(1), 127-144$

Cao, T. S., Luong, D. A., Vu, D. T., \& Ho, T. L. T. 2011. Surface Water Pollution Assessment at Difference Pig-farms in Hung Yen Province. Environment and Development Journal, 3, 393-401

Cassou, E., Tran, D. N., Nguyen, H. T., Dinh, X. T., Nguyen, V. C., Cao, T. B., Jaffee, S., \& Ju, J. 2017. "An Overview of Agricultural Pollution in Vietnam: Summary Report." Prepared for the World Bank, Washington

Chau, H., Ho, T., Nguyen, V. C., Pham, H. T. S., An, L. V., Fujieda, A., Ueru, T., \& Akamatshu, M. 2014. Microbial and Parasitic Contamination on Fresh Vegetables Sold in Traditional Markets in Hue City, Vietnam. Journal of Food and Nutrition Research, 2(12), 959-964

Delli, C. R., Gabrielli, M., Polesel, F., Turolla, A., Trapp, S., Vezzaro, L., \& Antonelli, M. 2020. Risk assessment of contaminants of emerging concern in the context of wastewater reuse for irrigation: An integrated modelling approach. Chemosphere, $\mathbf{2 4 2}$, 125-185

Helmecke, M., Fries, E., \& Schulte, C. 2020. Regulating water reuse for agricultural irrigation: Risks related to organic microcontaminants. Environmental Sciences Europe, 32(1), 4

Ho, T. L. T., Cao, T. S., Luong, D. A., Vu, D. T., Kurosawa, K., \& Egashira, K. 2013. Evaluation of Water Pollution Caused by Different Pig-Farming Systems in Hungyen Province of Vietnam. J. Fac. Agr., Kyushu Univ, 58(1), 159-165

Ho, T. L. T., Cao, T. S., Tran, T. L., Kurosawa, K., \& Egashira, K. 2010. Assessment of surface and groundwater quality in pigraising villages of Haiduong province in Vietnam. Journal of the Faculty of Agriculture, Kyushu University, 55(1), 123130

Huong, L. T. T., Takahashi, Y., Nomura, H., Son, C. T., Kusudo, T., \& Yabe, M. 2020. Manure management and pollution levels of contract and non-contract livestock farming in Vietnam. Science of The Total Environment, 710, 136-200

Jaramillo, M. F., \& Tarquino, I. R. 2017. Wastewater Reuse in Agriculture: A Review about Its Limitations and Benefits. Sustainability, $\mathbf{9}(10), 125-185$

Machado-Moreira, B., Richards, K., Brennan, F., Abram, F., \& Burgess, C. M. 2019. Microbial Contamination of Fresh Produce: What, Where, and How? Comprehensive Reviews in Food Science and Food Safety, 18(6), 1727-1750

MONRE. 2016. National Technical Standard on the effluent of livestock, QCVN62. Ministry of National Resource and Environment

MONRE. 2018. The National Environmental Report 2018: Water Quality in River Basins. Ministry of Natural Resources and Environment

Nguyen, T. H. 2018. The dual benefits of using livestock wastewater to irrigate crops. Vietnam Environment Administration Magazine, 3. http://tapchimoitruong.vn/pages/ article.aspx?item=L\%E1\%BB\%A3i-\% C3\% ADch-k\% C3\%A9p -t\% E 1\% B B \% AB-vi\% E 1\% B B \% 87c-s\% E 1\% B B \% AD - d \% E $1 \%$ B B \% A 5 ng -n \% C $6 \%$ B $0 \%$ E $1 \%$ B B \% 9 B cth $\%$ E $1 \%$ B A $\%$ A 3 i-ch $\%$ C $4 \% 83$ n-n u $\%$ C $3 \%$ B 4 it\% C6\%B0\%E1\%BB\%9Bi-cho-c\%C3\%A2y-tr\%E1\%BB\%93ng48201

Thanh Son, \& Nguyen Thuy. 2019. There is no need for environmental standards for livestock wastewater used as fertilizer. https://nongnghiep.vn/khong-can-tieu-chuan-moitruong-voi-nuoc-thai-chan-nuoi-lam-phan-bon-d247170.html

Van, D., Lam, N. T., Son, C. T., Cong, V. H., Bao, P., \& Kuyama, T. 2017. Pig manure and effluent management in Vietnam. Paper presented at WEPA Group Workshop on Pig Wastewater Management in Asia, ThaiLand

Vinh, N. Q. 2013. Wastewater reuse-Effective solution for environmental treatment in new rural areas. Vietnam Academy for Water Resources. http://www.vawr.org.vn/index. a s p x ? a a c = C L I C K \& a i d = A R T I C L E D E T A I L \& a r i = $2101 \& \mathrm{lan} g=1 \&$ m e n $u=\& \mathrm{mid}=-$ 135\&pid=1\&title=tai-su-dung-nuoc-thai--_giai-phap-hieuqua-trong-xu-ly-moi-truong-tai-cac-vung-nong-thon-moi

Vu, T. K. V., Tran, M. T., \& Dang, T. T. S. 2007. A survey of manure management on pig farms in Northern Vietnam. Livestock Science, 112(3), 288-297. https://doi.org/10.1016/j. livsci.2007.09.008

Williams, A. G., Audsley, E., \& Sandars, D. L. 2006. Determining the environmental burdens and resource use in the production of agricultural and horticultural commodities [Defra Research Project IS0205]. Cranfield University and Defra 